\title{
Forecasting Mobile Ticketing Adoption on Commuter Rail
}

\author{
Candace Brakewood, Georgia Institute of Technology \\ Dr. Francisca Rojas, Inter-American Development Bank \\ Joshua Robin, Masabi LLC \\ Jake Sion, Veolia Transportation \\ Sam Jordan, University of Massachusetts Amherst
}

\begin{abstract}
Several commuter rail systems are beginning to accept mobile payments, in which tickets are purchased and validated on smartphones. Mobile payments may improve the rider experience while reducing costs and simplifying the fare collection process for rail operators. Before investing in this new ticketing technology, rail operators want to understand rider demand for mobile tickets. To assess the potential adoption of mobile payments, stated preference data from an onboard survey on two commuter rail lines (Worcester and Newburyport/Rockport) in the greater Boston area were analyzed. Binary logit was then used to forecast adoption on all commuter rail lines. Based on this model, 26 percent of commuter rail riders in Boston are very likely to adopt mobile ticketing.
\end{abstract}

\section{Introduction}

Commuter rail services typically use conductor-validated or proof-of-payment fare collection systems. In conductor-validated schemes, such as Boston's commuter rail, riders either prepay or buy tickets from conductors onboard. To prepay, passengers purchase tickets at windows, vending machines, or local retailers. Passengers then present tickets to conductors onboard trains for validation. In proofof-purchase systems, riders must carry a valid ticket with them and are subject 
to random inspection (Multisystems, Inc. 2003). Typically, these two types of fare collection are used in barrier-free rail systems.

While these types of fare collection are common in suburban commuter rail services, there are a few noteworthy drawbacks. First, it can be expensive to install equipment and operate the ticketing facilities needed for prepayment in rail stations. Second, ticket windows and onboard fare collection typically involve a large number of cash transactions. This can inconvenience customers who prefer credit or debit payments, particularly if electronic payments are not accepted at ticket windows or onboard trains. There are also significant risks associated with operators handling high volumes of cash, such as theft or fraud.

Although many heavy rail systems in urban centers have transitioned to smartcard fare collection systems (Fleishman et al. 1998; Multisystems, Inc. 2003; Hong 2006; Acumen Building Enterprise, Inc. 2006), most suburban commuter rail networks do not accept contactless smartcard payments. One reason for this is high capital and operating cost projections for previously ungated rail systems; this includes installing gates or validation systems and maintaining fare equipment distributed over extensive geographic areas. Additionally, installing a smartcard system-particularly with barriers-involves a significant change in customer experience for most conductor-validated or proof-of-payment fare collection systems. For these reasons and others, commuter rail operators have struggled to adopt smartcard fare collection systems.

As an alternative strategy, many commuter rail operators are now considering mobile payments for fare collection. Mobile payments would enable riders to purchase tickets directly on their smartphones with a credit card, debit card, or other electronic payment. This option may improve the customer experience by replacing prepayment at ticket windows or vending machines, which typically require some amount of waiting in line, thereby saving travel time. Furthermore, mobile payment with credit and debit cards can help reduce the number of cash transactions at ticket windows and onboard trains. Finally, mobile purchases may provide rail operators with valuable planning data that are currently not available in cash-based systems (i.e., disaggregate origin and destination information). In light of these advantages, several commuter rail systems are beginning to implement mobile payment fare collection systems. 


\section{Objective}

Given interest in mobile payments, this research aimed to assess the level of demand for mobile payments by train riders. Stated preference survey data from two commuter rail lines in the greater Boston area were used in a discrete choice modeling framework to predict mobile payment adoption by riders. This model was then used to forecast demand for mobile payments on the entirety of Boston's commuter rail network.

Since most commuter rail operators do not yet accept mobile payments, there is limited information about the potential size of the market. Furthermore, other commuter rail operators may not have the resources to conduct detailed customer research to assess rider demand for mobile payments in their region. Therefore, this study also aimed to develop a simple methodology that other regional rail operators can use to estimate mobile ticketing adoption in their region. This methodology assumes that other operators have recent travel survey data, including rider demographics.

\section{Background on Mobile Payments}

Mobile payments enable riders to purchase tickets directly on their smartphones using a credit card, debit card, or other electronic payment. This transaction occurs in real-time over a cellular network and is then processed like a standard credit or debit transaction. Passengers may be required to activate their ticket before it is valid for travel. Operators then have several validation options, such as visually inspecting the smartphone ticketing screen or scanning a ticketing barcode with a hand-held device. This model of validation for mobile payments is applicable to commuter rail systems that rely on conductor-validated or proof-of-payment fare collection schemes.

Several commuter rail systems in the United States are moving toward mobile ticketing, and they are in different stages of assessment, procurement, testing, and implementation. Long Island Rail Road (LIRR) conducted a pilot program in which passengers could purchase mobile tickets for travel to a golf tournament and reported that approximately 20 percent of riders used mobile tickets to travel to the event (Mian 2012). Metro North Railroad (MNR) in New York and Connecticut recently tested mobile tickets with railroad staff, and the Metropolitan Transportation Authority (MTA) issued a request for proposals to move forward with mobile ticketing (MTA 2013). Similarly, Virginia Railway Express (VRE) in northern Virginia is in a procurement process for mobile ticketing (VRE 2013). Several transit agen- 
cies with proof-of-payment fare collection systems are also implementing mobile payment systems, including TriMet in Portland (TriMet 2013) and DART in Dallas (DART 2012).

Despite the interest in mobile ticketing by regional rail operators throughout the country, there is very little literature pertaining to mobile payments for commuter rail fare collection. Most prior research has focused on mobile payments using near-field communications (NFC) technology and its application to urban bus and subway systems (Dorfman 2007; Quibria 2008; NFC Forum 2012). Consequently, additional research could provide significant insight for commuter rail operators considering mobile ticketing systems; the following analysis begins to fill this gap in the literature.

\section{Background on Commuter Rail in Boston}

This study analyzes the new mobile ticketing pilot program on commuter rail in Boston (Moskowitz 2012). The commuter rail is operated by the Massachusetts Bay Commuter Rail Company (MBCR) under contract with the Massachusetts Bay Transportation Authority (MBCR 2012). This operation includes fixed-schedule, daily service on 14 lines serving downtown Boston via two central city stations (North Station and South Station). It is the fifth largest commuter rail system in the United States based on the number of unlinked passenger trips (APTA 2011).

Boston's commuter rail has a zone-based fare policy, and both period passes (monthly) and pay-per-ride (single or multi-ride) tickets are available. Fare collection is administered through a conductor-validated system. Riders can prepay for tickets in rail stations at vending machines or at ticket windows, although many outlying stations lack ticketing facilities. Commuting riders can also purchase tickets through pre-tax employer programs, with participating companies in greater Boston distributing tickets directly to corporate program customers. Once onboard, conductors validate single- and multi-ride tickets using a hole-punch, and monthly passes are simply shown to conductors as flash passes. Passengers also have the option of purchasing single-ride tickets from the conductor onboard with cash at a higher price (MBTA 2012).

In late 2006, the Massachusetts Bay Transportation Authority (MBTA) launched the CharlieCard smartcard and magnetic stripe fare collection system on MBTA buses, subway, and light rail (Ryan 2007). The only part of the CharlieCard system that integrates with commuter rail is monthly passes; the backside of the com- 
muter rail flash pass has a magnetic stripe ticket that can be used for free transfers onto MBTA subway trains and buses.

Over the past six years, there has been significant interest in expanding the CharlieCard system to commuter rail (Goodison 2007). Due to various constraintsmost importantly, cost-this has not happened. The MBTA originally invested more than $\$ 150$ million in the CharlieCard system for subway, bus, and light rail. When proposals for expansion to the commuter rail estimated more than $\$ 70$ million in costs, the MBTA chose to pursue an alternative strategy.

In early 2012, the MBTA announced a one-year pilot program for mobile ticketing on commuter rail. This program has minimal upfront costs; the company contracted out the provision of the mobile ticketing platform for 2.8 percent of ticket sales (Moskowitz 2012). The pilot program officially launched in November 2012, and riders on all commuter rail lines are now able to purchase single- and multiride tickets via Android and iPhone smartphones. Monthly passes are also available as mobile tickets, but they currently do not include free transfers to MBTA bus or subway (MBTA 2013).

Riders who participate in the pilot program can purchase mobile tickets for their selected journey (see left screen in Figure 1) using a credit or debit card (see middle screen in Figure 1). Riders then activate their tickets before boarding, and once onboard, conductors can validate mobile tickets by visually inspecting them (see right screen in Figure 1). For further validation, tickets include a barcode that can be scanned to ensure fare compliance.

While the MBTA was planning the mobile ticketing pilot program, it worked in coordination with researchers (authors Brakewood and Rojas) to conduct detailed customer research about the potential adoption of mobile ticketing in Boston, which is described in the following paragraphs. 


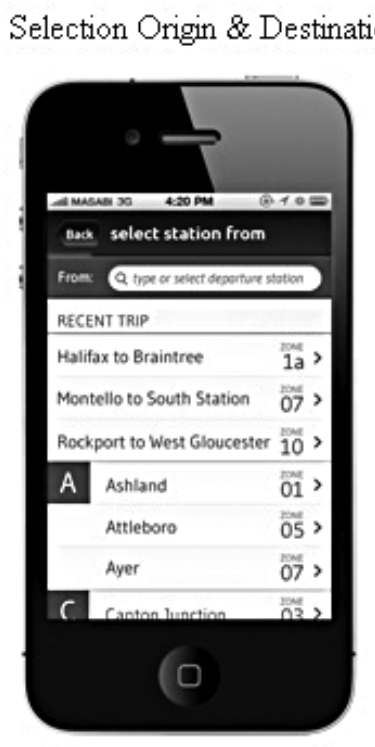

Purchase Ticket

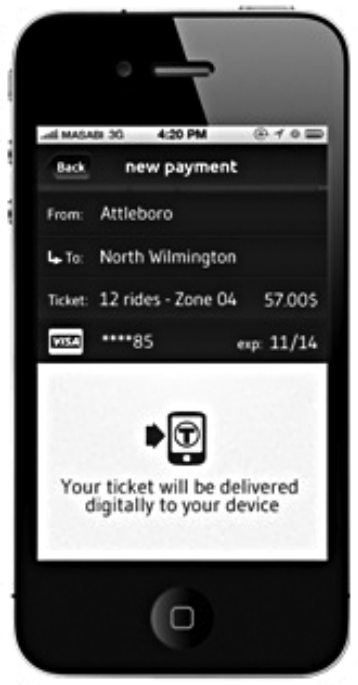

Display Active Ticket

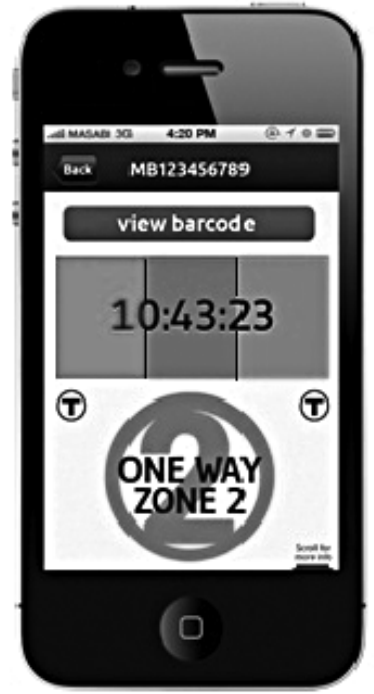

Figure 1. Demonstration screenshots of commuter rail mobile ticketing application

\section{Data Collection}

The authors and a small group of graduate students conducted a short onboard survey to collect data for this analysis. An onboard sampling method was selected to ensure that only those in the target population (commuter rail riders) were reached. The survey was administered on three weekdays in June 2012 during the AM and PM peak periods (approximately 6:30-10 AM and 4-7:30 PM). Because ridership on the commuter rail is highly peaked in the commuting direction (inbound in the AM, outbound in the PM), the off-peak direction (outbound in the $A M$, inbound in the PM) was also sampled, so that both peak and off-peak riders could be included in the analysis. A total of 12 different train trips were sampled; 6 were outbound trips and 6 were inbound trips. Once onboard the trains, teams of two or three distributed paper surveys to as many riders as possible.

\section{Line Selection}

Due to manpower constraints, all commuter rail lines could not be sampled. Instead, two representative lines were selected for this analysis: the Worcester and Newburyport/ Rockport lines. These lines were selected to best represent the 
population of commuter rail riders as a whole. Three factors influenced this selection: geography, ridership levels, and diversity of ridership.

The first factor, geography, was defined based on the terminal stations in downtown Boston. Two large commuter rail stations serve as the terminus for most commuter rail trips (North Station and South Station). Differences in service provision-particularly ticketing facilities at these two locations-could impact adoption of mobile ticketing. The first line that was selected (Newburyport/Rockport) terminates at North Station, and the second line (Worcester) ends at South Station. Second, only high ridership lines were considered to maximize the response rate during the data collection process. Both of the selected lines have average weekday boardings of approximately 17,000-18,000 (cumulative counts for the Newburyport and Rockport branches), which makes them two of the highest ridership lines within the overall commuter rail network (MBTA 2010).

Third, the diversity of rider income levels and ethnicities from previous survey results was considered. This factor was hypothesized to impact the level of technology adoption and, therefore, the potential for mobile ticketing adoption. The Worcester line has relatively high levels of demographic diversity, whereas the Newburyport/Rockport line has a relatively homogenous ridership (CTPS 2011).

\section{Data Collection Constraints}

Although standard procedures for survey research were followed, there were a few constraints on the data collection process. First, there was no mail-back option for the survey. Riders were instructed to complete as many questions on the survey as possible during their commute, but some surveys were left incomplete because the rider alighted the train. Additionally, since the survey was administered only in English, a very small number of riders (less than 10) declined participation because they did not speak English. Last, for most of the sampled trips, the data collection process did not extend to the outlying terminal station. There are very few commuter rail trips with boardings and alightings between the outermost stations based on previous survey results (CTPS 2011). Therefore, it is reasonable to assume that additional data collection efforts between these stops would not have had a significant impact on the results.

\section{Total Responses}

Overall, 914 surveys were collected during the fieldwork period, and 903 were deemed sufficiently complete for the following analysis. Sufficient completeness meant that the respondent answered the questions up to and including the stated 
preference mobile ticketing question (question 18 on the survey instrument). Table 1 shows the number of completed surveys collected on each line during each time period. The paper surveys were coded by the authors, and a sample of 5 percent was cross-checked for any data entry errors.

Table 1. Commuter Rail Surveys by Time Period and Line

\begin{tabular}{|c|c|c|c|c|c|c|c|}
\hline Date & Day & Time & Line & $\begin{array}{l}\text { Inbound } \\
\text { Surveys }\end{array}$ & $\begin{array}{c}\text { Outbound } \\
\text { Surveys }\end{array}$ & $\begin{array}{c}\text { Total } \\
\text { Surveys }\end{array}$ & $\begin{array}{c}\% \text { of } \\
\text { Total* }\end{array}$ \\
\hline June 12, 2012 & Tues & $A M$ & Worcester & 75 & 62 & 137 & $15 \%$ \\
\hline June 12, 2012 & Tues & PM & Newburyport & 36 & 153 & 189 & $21 \%$ \\
\hline June 13, 2012 & Wed & AM & Newburyport & 123 & 17 & 140 & $16 \%$ \\
\hline June 13, 2012 & Wed & PM & Worcester & 81 & 160 & 241 & $27 \%$ \\
\hline June 14, 2012 & Thurs & AM & Worcester & 89 & 2 & 91 & $10 \%$ \\
\hline June 14, 2012 & Thurs & PM & Rockport & 33 & 72 & 105 & $12 \%$ \\
\hline \multicolumn{4}{|c|}{ Total } & 437 & 466 & 903 & $100 \%$ \\
\hline
\end{tabular}

*Percentages rounded to the nearest whole number.

\section{Survey Content}

The survey instrument contained four questions designed to capture topics relevant to the use of mobile ticketing. First, the survey included a question about the adoption of information and communications technologies that could be used to access mobile ticketing applications, particularly smartphones. Second, the use of mobile payments for other retail transactions (i.e., Starbucks) was investigated using a revealed preference question. Then, after a brief description of mobile payments on the commuter rail, a stated preference survey question was posed to assess the likelihood of participants adopting mobile ticketing. This was followed by a question that probed the respondents' opinions about mobile payments (i.e., reasons for preferring mobile purchases or not).

\section{Statistical Analysis}

A high-level statistical analysis was performed on the four key questions that pertained to mobile ticketing, and the results are summarized in Table 2. This table contains the exact wording used for each of the four questions in the survey instrument, including the description of the stated preference question for mobile ticketing. 

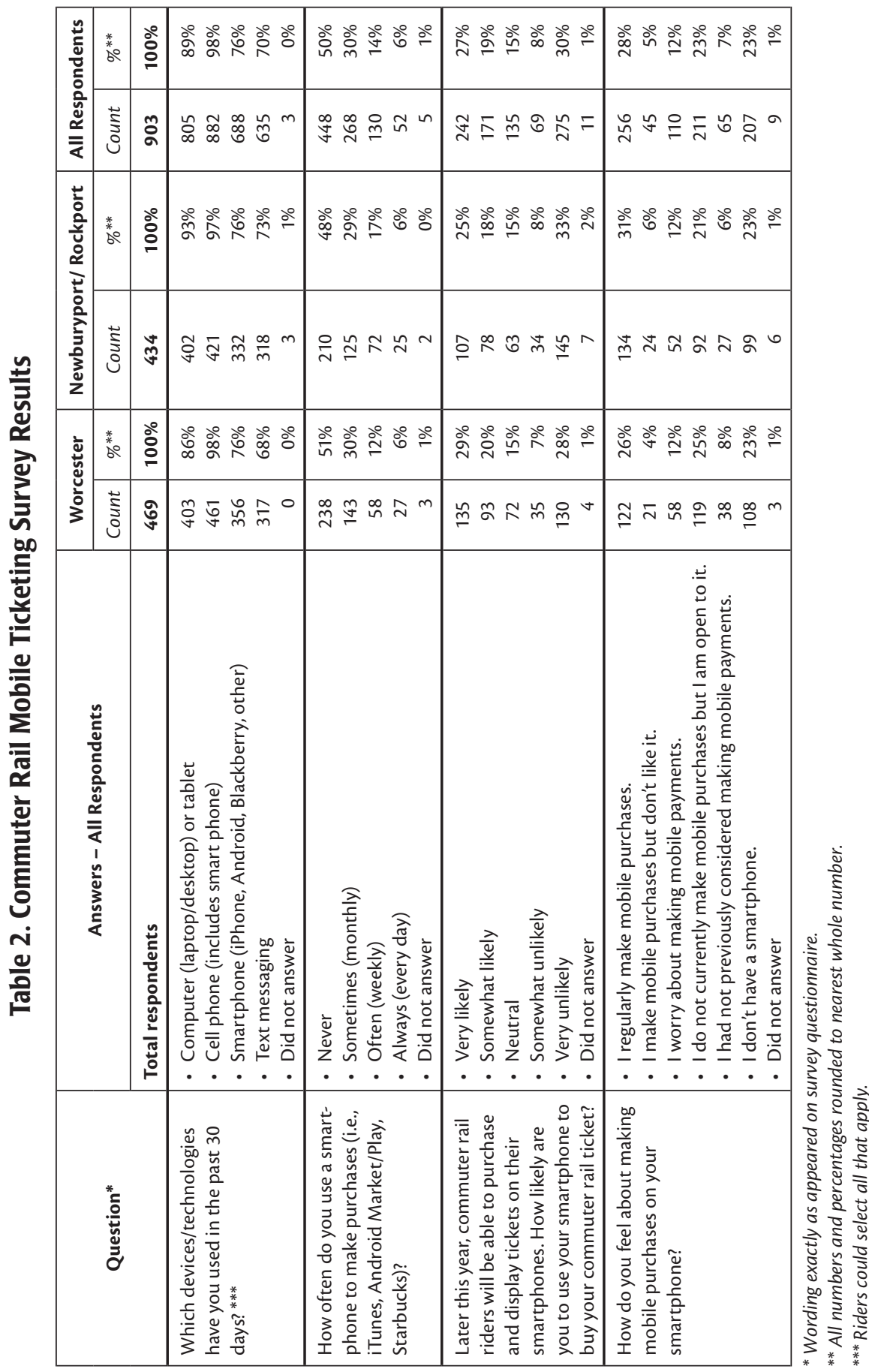
As can be seen in Table 2, riders were first asked what devices/technologies they have used in the past 30 days, which included different types of smartphones. This question is crucial to forecasting the potential mobile ticketing market size, since riders without smartphones will be unable to participate in the MBTA's mobile ticketing initiative. The results show that approximately 76 percent of riders use smartphones, and the most popular smartphone is the iPhone. As a basis for comparison, approximately 55 percent of U.S. mobile subscribers own smartphones as of June 2012 (Streams 2012). These high adoption rates suggest that mobile ticketing is well suited for Boston's commuter rail.

Next, riders were asked how often they use a smartphone to make purchases (i.e., iTunes, Android Market/Play, Starbucks). Fifty percent of riders make mobile purchases once a month or more. Among the 50 percent who do not make mobile purchases, almost half do not use smartphones.

Then, the survey instrument informed riders that they would be able to purchase and display tickets on their smartphones later this year, and they were asked how likely they are to use their smartphone to buy a commuter rail ticket. A total of 29 percent of Worcester riders and 25 percent of Newburyport/Rockport riders indicated that they are very likely to use mobile ticketing. These riders are likely to be early adopters of mobile ticketing. Similarly, 20 percent of Worcester riders and 18 percent of Newburyport/Rockport riders indicated that they are somewhat likely to use mobile ticketing, whereas 22 percent of Worcester riders and 23 percent of Newbury/Rockport riders said they were neutral or somewhat unlikely to use mobile ticketing. This second group of riders may eventually use the technology, but it is doubtful that they will be early adopters. Last, 28 percent of Worcester riders and 33 percent of Newburyport/Rockport riders indicated they were very unlikely to use mobile ticketing.

Finally, riders were asked how they feel about making mobile purchases on their smartphones, which is intended to gauge rider attitudes towards mobile ticketing. The majority of riders stated that they already make mobile purchases (including those who do not like it) or are open to doing so (55\% of Worcester riders and $58 \%$ of Newburyport/Rockport riders). Others were worried about making mobile purchases or had never even considered it (20\% of Worcester riders and $18 \%$ of Newburyport/Rockport riders). These results show that if agencies aim to increase adoption rates, they must consider how to attract this demographic. The remaining 23 percent of riders on both the Worcester and Newburyport/Rockport lines said they did not have smartphones to make mobile purchases. 
One additional caveat should be made about the statistics presented in the previous two paragraphs. All respondents were able to answer the questions pertaining to mobile ticketing for commuter rail and their feelings about mobile purchases, regardless of whether or not they currently use a smartphone. Sixteen respondents (1.7\% of 903 total surveys) said they were "very likely" to use mobile ticketing, but answered the previous question by stating that they had "not used a smartphone in the past 30 days." While this answer appears to be counterintuitive, six of these respondents had used a tablet (iPad, Kindle) in the past 30 days, and therefore, they may have assumed that mobile ticketing options would be available on these devices. Additionally, 2 of these 16 respondents answered the last question by saying "I do not currently make mobile purchases, but I am open to it." One possible explanation is that these riders may be considering purchasing a smartphone/ tablet in the future, which is a logical conclusion since the adoption rates of these devices are rapidly growing. Finally, the remaining 8 of 16 respondents may have answered the mobile ticketing question in error, but this is a relatively low error rate for a sample of more than 900 participants.

\section{Forecasting Analysis}

To estimate the probability that a respondent will choose to adopt mobile ticketing, the survey data were used in a discrete choice modeling framework. This model was then used with a sample enumeration forecasting technique to estimate the total percentage of commuter rail riders who are likely to adopt mobile ticketing.

\section{Specification and Estimation of the Discrete Choice Model}

The first step in this analysis was to specify a discrete choice model. The coefficients of the parameters in the model allow for interpretation of the extent to which socioeconomic characteristics of the respondent relate to choice of mobile ticketing versus existing fare media. This is different from discrete choice models commonly discussed in the transit fare policy literature that are based on ticket price (Hong 2006; Zureiqat 2008). Instead, this modeling framework rests on the assumption that mobile tickets are inherently different from the existing fare media (namely paper tickets). This framework was recently applied to the demand for open payment systems (Brakewood 2010; Brakewood and Kocur 2011).

A binary logit model (Ben-Akiva and Lerman 1985) was specified in which the choice set was those who stated they were "very likely" to use mobile ticketing versus everyone else, who were assumed to continue using existing fare media. This modeling framework was selected because those who responded "very likely" 
will presumably be early adopters of mobile ticketing, and will therefore have the highest likelihood of participating in the MBTA pilot program.

The open source software package BIOGEME was used for estimation of this discrete choice model (Bierlaire 2010). The independent variables available for this analysis included socioeconomic and travel characteristics of the respondent, which were selected because they aligned with variables available for the forecasting exercise based on previous system-wide survey results (discussed in the following paragraphs). The data from both sampled lines were pooled for this analysis, and the sample size was reduced from 903 to 651 because many survey participants did not complete the demographic questions (namely income and ethnicity). After assessing multiple specifications using these independent variables, the binary logit specification shown in Table 3 was selected as having the most explanatory power while conforming to the constraints above.

\section{Discussion of the Binary Logit Model}

The following conclusions can be drawn from the results of the binary logit model. The negative alternative specific constant (-2.94) for mobile ticketing indicates that, all else being equal, the existing fare medium is the preferred alternative. Additionally, the relatively large magnitude of this constant compared to the other coefficients indicates that there is a high level of unexplained preference between the two alternatives.

The first independent variable, age, demonstrates that individuals below age 45 are more likely to adopt mobile ticketing, which is indicated by the positive coefficients of the other age variables. Examining the magnitude of the coefficients reveals that as age increases, the respondent is less likely to use mobile ticketing.

Conversely, the coefficients for household income show that as income increases, the likelihood of using mobile ticketing increases. This is shown by the positive coefficients for income, which has a reference group of the lowest household incomes.

For ethnicity, minority groups are somewhat less likely to use mobile ticketing than Caucasian riders, as demonstrated by their negative coefficients. It should be noted that "Hispanic" was asked separately from ethnicity, and the positive coefficient of the "Hispanic" variable indicates that they are more likely to adopt mobile ticketing than non-Hispanic riders.

Frequency of travel and gender were not statistically significant, as indicated by t-statistics of less than 1.5 . 
Last, the overall goodness of fit of the model is moderately low. An adjusted Rhosquared of 0.16 suggests that the independent variables have a somewhat limited relationship with fare medium intention.

Table 3. Binary Logit Results

\begin{tabular}{|c|c|c|c|}
\hline \multicolumn{4}{|c|}{ Very Likely to Use Mobile Ticketing } \\
\hline \multirow[t]{2}{*}{ Category } & Independent Variable & Coefficient & T-statistic \\
\hline & Alternative Specific Constant & -2.94 & -5.81 \\
\hline \multirow[t]{4}{*}{ Age } & Age 45 and older (reference) & - & - \\
\hline & Age 35 to 44 & 0.39 & 1.42 \\
\hline & Age 25 to 34 & 1.25 & 5.07 \\
\hline & Age 24 and under & 1.27 & 4.17 \\
\hline \multirow[t]{4}{*}{ Annual Income } & Less than $\$ 39,999$ (reference) & - & - \\
\hline & $\$ 40,000$ to $\$ 49,999$ & 0.83 & 1.92 \\
\hline & $\$ 50,000$ to $\$ 74,999$ & 0.96 & 2.34 \\
\hline & $\$ 75,000$ or more & 1.23 & 3.27 \\
\hline \multirow[t]{4}{*}{ Ethnicity } & Caucasian (reference) & - & - \\
\hline & Asian & -0.03 & -0.12 \\
\hline & African American & -1.17 & -1.62 \\
\hline & Other & -1.16 & -1.94 \\
\hline \multirow[t]{2}{*}{ Hispanic } & Not Hispanic (reference) & - & - \\
\hline & Hispanic & 0.75 & 1.46 \\
\hline \multirow[t]{4}{*}{ Travel Frequency } & 1 day or less per week (reference) & - & - \\
\hline & 2 to 4 days per week & 0.36 & 0.96 \\
\hline & 5 days per week & 0.21 & 0.61 \\
\hline & 6 to 7 days per week & 0.89 & 1.37 \\
\hline \multirow[t]{2}{*}{ Sex } & Female (reference) & - & - \\
\hline & Male & 0.17 & 0.9 \\
\hline \multirow[t]{6}{*}{ Summary Statistics } & Number of observations & \multicolumn{2}{|c|}{651} \\
\hline & Initial log likelihood & \multicolumn{2}{|c|}{-451.24} \\
\hline & Final log likelihood & \multicolumn{2}{|c|}{-365.38} \\
\hline & Likelihood ratio test & \multicolumn{2}{|c|}{171.72} \\
\hline & Rho-Squared & \multicolumn{2}{|c|}{0.19} \\
\hline & Adjusted Rho-Squared & \multicolumn{2}{|c|}{0.16} \\
\hline
\end{tabular}




\section{Forecasting}

After estimating the discrete choice model, a forecasting analysis was conducted using sample enumeration to predict the adoption of mobile ticketing on the entire commuter rail network. The data used in the forecasting exercise are from the Central Transportation Planning Staff (CTPS) commuter rail survey conducted in 2008-2009. This system-wide survey asked questions pertaining to travel behavior and demographic information needed for the Boston area travel demand model; questions about technology adoption were not asked. Therefore, the forecasting analysis was constrained by the questions available from this system-wide survey.

CTPS provided the authors with the raw data from this system-wide survey for all commuter rail questions pertaining to gender, age, ethnicity, household income, and frequency of travel. The total sample size of the CTPS dataset was 12,960 respondents, but this was reduced to 10,407 because some respondents did not answer all of the demographic questions (namely household income). The CTPS dataset included a weight for each respondent to assure system-wide representativeness. Weights were not used in the sample enumeration calculation. Once the sample enumeration was performed, the probability that each rider would use mobile ticketing was then weighted by the original value provided by CTPS, and these weighted probabilities were aggregated to determine the total adoption rate on the commuter rail network. The results of this analysis reveal that approximately 26 percent of commuter rail riders are very likely to adopt mobile ticketing.

\section{Modeling Constraints and Areas for Improvement}

This analysis aimed to provide a simple methodology to forecast mobile ticketing adoption. Initially, an ordinal logit specification including all mobile ticketing preference levels was tested, but the goodness-of-fit was extremely low, implying that levels of preference other than "very likely" were not reliable indicators of intention. Therefore, the simple binary logit model was selected for presentation in this paper.

To improve this analysis, more sophisticated methodologies could be used. For example, the discrete choice model could include more complicated specifications, such as nesting the stated mobile ticketing intention question within the revealed preference of past mobile purchase behavior. Such a model might add insight into the behavior of riders considering adoption of mobile ticketing but, unfortunately, it would not permit forecasting given the datasets available for this specific analysis. Furthermore, other commuter rail operators who have only standard travel 
survey information would not be able to easily adapt more sophisticated discrete choice models to forecast mobile payment adoption in their regions. In summary, the discrete choice methodology presented in this paper should be treated as a simple forecasting approach, and future research could aim to improve the model specification.

Additionally, this modeling approach relies completely on stated preference data about mobile ticketing. Because stated intention does not always align with actual behavior, this analysis could be improved in the future by combining the dataset with actual adoption information that could become available within the year.

Last, this forecasting method assumes that all fare types will be included in the mobile ticketing pilot program; similarly, it assumes that the corresponding fares will not be raised or lowered. At this time, the pilot program does not include monthly passes with free transfers, although it is anticipated that this will be added in the future. Additionally, the pilot program does not have plans for distribution of tickets purchased through corporate pass programs. Based on the survey results, approximately 30 percent of Worcester and 42 percent of Newburyport/Rockport riders purchase their tickets through pre-tax employer programs. Because of this constraint, the actual adoption of mobile ticketing in the commuter rail pilot program is likely to be lower than the forecasted results.

\section{Conclusions}

This research demonstrates significant potential for adoption of mobile ticketing on the commuter rail network in Boston. The onboard survey data revealed that there are high levels of technology use by riders, with approximately 76 percent of riders using smartphones and 50 percent making mobile purchases at other merchants. Mobile ticketing offers these riders a more convenient purchase method than prepayment at ticket windows or vending machines and is less problematic (for both the customer and operator) than onboard cash transactions. Furthermore, it is a low cost option for the MBTA and other rail operators to capitalize on existing infrastructure-the widespread adoption of smartphones among their riders-rather than installing gates or validation systems over extensive geographic areas.

To assess the potential adoption of mobile payments, stated preference data from an onboard survey on two MBTA commuter rail lines in the greater Boston area were analyzed. Binary logit was used to forecast adoption on the entire rail network, and the results showed that approximately 26 percent of all commuter 
rail riders stated that they are likely to adopt mobile ticketing. Considering the dearth of research about the potential size of the market, this forecast should help the MBTA and other agencies make informed decisions regarding mobile ticketing. Moreover, the survey data provided important information concerning rider attitudes towards adoption of mobile ticketing, offering rail operators additional statistics. In light of this research and the widespread adoption of smartphones, mobile ticketing appears to be a compelling alternative to traditional ticketing methods, and its adoption by rail operators and utilization by riders are likely to increase in the near future.

\section{Acknowledgments}

This research was funded in part by a Rappaport Institute Public Policy Summer Fellowship, the Singapore MIT Alliance for Research and Technology, a U.S. DOT Eisenhower fellowship, a WTS-Boston Fellowship, and a University Transportation Center grant. The authors would like to acknowledge the Transparency Policy Project at Harvard University and Professor Chris Zegras at Massachusetts Institute of Technology for their support. Thanks to Dr. David Block-Schachter at MIT for his advice on the forecasting methodology and to CTPS for providing the systemwide commuter rail survey data for the forecasting analysis. Last, a sincere thanks to the MIT graduate student volunteers who helped collect surveys onboard the commuter rail trains.

\section{References}

Acumen Building Enterprise, Inc. 2006. Smartcard interoperability issues for the transit industry. Transit Cooperative Research Program Report 115, Transportation Research Board.

American Public Transportation Association (APTA). 2011. 2011 Public Transportation Fact Book 62nd Edition: 31.

Ben-Akiva, M., and S. Lerman. 1985. Discrete Choice Analysis: Theory and Application to Travel Demand. MIT Press, Cambridge, MA.

Bierlaire, M. An introduction to BIOGEME 1.8. Transport and Mobility Laboratory, École Polytechnique Fédérale de Lausanne. Accessed July 29, 2010. http:// biogeme.epfl.ch. 
Brakewood, Candace. 2010. Contactless prepaid cards and bankcards in transit fare collection systems. MS Thesis, Massachusetts Institute of Technology.

Brakewood, Candace, and George Kocur. 2011. Modeling transit rider preferences for contactless bank cards as fare media transport for London and the Chicago Transit Authority. Transportation Research Record 2216: 100-107.

Central Transportation Planning Staff (CTPS). 2010. Commuter rail, all lines 200809. MBTA Systemwide Passenger Survey. Accessed July 27, 2012. http://www. ctps.org/bostonmpo/4_resources/1_reports/1_studies/3_transit/MBTA_Passenger_Survey/Commuter_Rail_Volume.pdf.

Dallas Area Rapid Transit (DART). 2012. RFP No. P-1021873, Comprehensive Fare Payment System (CFPS) Mobile Ticketing Application. Accessed July 26, 2012. http://www.dart.org/webapps/procurement/solicitation/solfiles/amendments/1021873\%20amd\%2004.pdf.

Dorfman, Matthew. 2007. Future contactless payment options for transport for London: Demand, cost, equity, and fare policy implications. MS Thesis, Massachusetts Institute of Technology, Cambridge, MA.

Fleishman, D., C. Schweiger, D. Lott, and G. Pierlott. 1998. Multipurpose transit payment media. Transit Cooperative Research Program Report 32, Transportation Research Board.

Goodison, Donna. 2007. CharlieCard setup coming to commuter rail. Boston Herald. Accessed July 27, 2012. http://www.boston.com/news/local/breaking_news/2007/12/charliecard_cel.html.

Hong, Y. 2006. Transition to smart card technology: How transit operators can encourage the take-up of smart card technology. MS Thesis, Massachusetts Institute of Technology.

Massachusetts Bay Commuter Railroad Company (MBCR). 2012. Who we are. Accessed July 27, 2012. http://www.mbcr.net/who_we_are.html.

Massachusetts Bay Transportation Authority (MBTA). 2010. Ridership and service statistics, thirteenth edition. Accessed July 27, 2012. http://www.mbta.com/ uploadedfiles/documents/Bluebook\%202010.pdf.

MBTA. 2012. Commuter rail fares \& passes. Accessed July 27, 2012. http://www. mbta.com/fares_and_passes/rail/. 
MBTA. 2013. Ticket for commuter rail and ferry. Accessed June 17, 2013. http:// www.mbta.com/fares_and_passes/mticketing/?id=25903\#3.

Metropolitan Transportation Authority (MTA). 2013. Train tickets? There could be an app for that! Accessed June 17, 2013. http://new.mta.info/train-ticketsthere-could-be-app.

Mian, Rashed. 2012. Mobile ticketing may soon come to LIRR. Accessed November 13, 2012. http://www.longislandpress.com/2012/09/04/mobile-ticketing-maysoon-come-to-lirr/.

Moskowitz, Eric. 2012. MBTA mobile-ticket era begins for commuter rail riders Monday. Boston Globe. Accessed November 13, 2012. http://www.boston.com/ news/local/massachusetts/2012/11/12/mbta-mobile-ticket-era-begins-forcommuter-rail-riders-monday/aCaqkieVoYj8pfhELqgJRN/story.html.

Multisystems, Inc. 2003. Fare policies, structures and technologies: Update. Transit Cooperative Research Program Report 94, Transportation Research Board: 23.

NFC Forum. 2011. NFC in public transport. NFC Forum, Inc. Wakefield, Massachusetts. Accessed November 13, 2012. http://www.nfc-forum.org/resources/ white_papers/NFC_in_Public_Transport.pdf.

Quibria, Nasreen. 2008. The contactless wave: A case study in transit payments. Federal Reserve Bank of Boston.

Ryan, Andrew. 2007. CharlieCard celebrates its first birthday. Boston Globe. Accessed July 27, 2012. http://www.boston.com/news/local/breaking_news/2007/12/ charliecard_cel.html.

Streams, Kimber. 2012. Nielsen: Android growing faster than Apple, both companies edge out competitors. Vox Media. Accessed July 30, 2012. http:// www.theverge.com/2012/7/12/3155378/nielsen-smartphones-android-applegrowth.

TriMet. 2013. Pay your TriMet fare instantly on your smartphone. Accessed June 17, 2013. http://trimet.org/mobiletickets/.

Virginia Railways Express (VRE). 2013. VRE Mobile Ticketing System Request for Proposals (RFP) \#013-004. Accessed June 17, 2013. http://www.vre.org/about/ procurement/rfp_013-004_mobile_ticketing/rfp_013-004_mobile_ticketing. html. 
Zureiqat, H. 2008. Fare policy analysis for public transport: A discrete-continuous modeling approach using panel data. MS Thesis, Massachusetts Institute of Technology.

\section{About the Authors}

CANDACe BraKewood (candace.brakewood@gatech.edu) is pursuing a Ph.D. in Transportation Systems in the School of Civil and Environmental Engineering at Georgia Tech. Her doctoral research evaluates the impact of real-time bus and train tracking information on transit rider behavior. She has two M.S. degrees from the Massachusetts Institute of Technology and a B.S. in Mechanical Engineering from Johns Hopkins University.

Dr. Francisca Rojas (franciscar@iadb.org) is an Urban Development Specialist at the Inter-American Development Bank. Previously, she was Research Director with the Transparency Policy Project at the Kennedy School of Government at Harvard University. She has a Ph.D. in Urban and Regional Planning from the Massachusetts Institute of Technology.

JoshUA RoBin (josh.robin@masabi.com) is Masabi's Vice President for Strategy and Development - North America. In this role, he is responsible for working with U.S. transit agencies to deploy Masabi's mobile ticketing and agile fare collection systems. Prior to joining Masabi, he was the Director of Innovation for MBTA in Boston. While at MBTA, he led a number of digital communications efforts, including the launch of the United States' first mobile ticketing system on commuter rail, implementation of countdown signs on the T's heavy rail lines, and the release of real-time bus information.

JAKE SION (jakesion@gmail.com) is a Project Analyst at Veolia Transportation in New York. Previously, he interned at MBTA. He has a bachelor's degree from the College Scholar Program at Cornell University.

SAMUEL JORDAN (smjordan@student.umass.edu) is a senior at the University of Massachusetts, Amherst where he is pursuing a B.A. in Economics with a minor in Computer Science. He has worked for the Massachusetts Department of Transportation and is currently a senior editor of the Massachusetts Undergraduate Journal of Economics. 